\title{
PRODUKSI BIOGAS DARI CAMPURAN KOTORAN AYAM, KOTORAN SAPI, DAN RUMPUT GAJAH MINI (Pennisetum Purpureum cv. Mott) DENGAN SISTEM BATCH
}

\section{PRODUCING BIOGAS FROM CHICKEN MANURE, COW MANURE, AND MINI ELEPHANT GRASS (Pennisetum purpureum cV. Mott) BY BATCH SYSTEM}

\author{
Yasin Yahya ${ }^{1}$, Tamrin ${ }^{2}$, Sugeng Triyono ${ }^{2}$ \\ ${ }^{1}$ Mahasiswa Teknik Pertanian, Fakultas Pertanian, Universitas Lampung \\ ${ }^{2}$ Dosen Jurusan Teknik Pertanian, Fakultas Pertanian, Universitas Lampung \\ komunikasi penulis, e-mail : yasinyahya0910@gmail.com \\ Naskah ini diterima pada 20 Oktober 2017; revisi pada 15 November 2017; \\ disetujui untuk dipublikasikan pada 15 Desember 2017
}

\begin{abstract}
Biogas is one of an alternative energy that can be developed into one solution of solving energy crisis. Biogas is actually the resulted by anaerobic fermentation of organic material into methane gas $\left(\mathrm{CH}_{4}\right)$. Methane gas $\left(\mathrm{CH}_{4}\right)$ from biogas production can be used as gas fuel. This study would manufacture biogas, produced by a mixture of chicken manure, cow dung and mini elephant grass (pennisetum purpureum cv. Mott) in a 2 Litre volume of batch digester. This study used four mixed treatment of chicken manure, cow dung and mini elephant grass those are A 0: 100: 0, B 0:80:20, C 20:60:20, and D 30:20:50. The objective of study was to determine the approximately perfect mix for producing biogas. The finding of study showed that the optimum $\mathrm{C} / \mathrm{N}$ ratio for biogas production was $A 27,52, B 25,47$ and $C 22,23$ while $D$ was below optimum 19.18. The results of production of biogas treatment A $4916 \mathrm{~mL}, B 4610 \mathrm{~mL}, C 3909 \mathrm{~mL}$ and $D 2640 \mathrm{~mL}$. Biogas yields of treatment were as A $60.71 \mathrm{~mL} / \mathrm{g} \mathrm{VS}, B 109.58$ $\mathrm{mL} / \mathrm{g}$ VS, $C 134.29 \mathrm{~mL} / \mathrm{g}$ VS and $D 53.88 \mathrm{~mL} / \mathrm{g}$ VS. The burning test of treatment $A$ and $B$ produced a blue fire, $C$ was yellowish blue then $D$ did not. The most optimized treatments were A and B for producing maximum biogas based on total biogas production, $C / N$ ratio and the burn test result.
\end{abstract}

Keywords: mini elephant grass, biogas production, $C / N$ ratio, burn test

\begin{abstract}
ABSTRAK
Biogas merupakan energi alternatif yang dapat dikembangkan untuk menjadi salah satu solusi krisis energi. Biogas merupakan hasil fermentasi anaerob bahan organik menjadi gas metana $\left(\mathrm{CH}_{4}\right)$. Gas metana $\left(\mathrm{CH}_{4}\right)$ hasil produksi biogas dapat dijadikan menjadi bahan bakar gas. Penelitian biogas ini memproduksi biogas dari campuran kotoran ayam, kotoran sapi dan rumput gajah mini (pennisetum purpureum cv. Mott) dalam digester volume $2 \mathrm{~L}$ dengan sistem batch. Penelitian biogas ini menggunakan empat perlakuan campuran kotoran ayam, kotoran sapi dan rumput gajah yaitu A 0:100:0, B 0:80:20, C 20:60:20, dan D 30:20:50. Penelitian ini bertujuan untuk mengetahui campuran optimum untuk produksi biogas. Hasil penelitian diperoleh nilai optimum rasio C/N untuk produksi biogas yaitu perlakuan A 27,52, B 25,47, dan C 22,23 sedangkan D dibawah optimum yaitu 19,18. Hasil produksi biogas perlakuan A 4916 mL, B $4610 \mathrm{~mL}$, C $3909 \mathrm{~mL}$ dan D $2640 \mathrm{~mL}$. Produktivitas biogas perlakuan A 60,71 mL/g VS, B 109,58 mL/g VS, C 134,29 mL/g VS dan D 53,88 mL/g VS. Uji nyala masingmasing perlakuan A dan B menghasilkan api berwarna biru, C api berwarna biru kekuningan dan D tidak dapat menyala. Perlakuan A dan B paling optimum untuk produksi biogas berdasarkan total produksi biogas, rasio C/ $\mathrm{N}$ dan hasil uji nyala.
\end{abstract}

Kata Kunci: Rumput gajah mini, produksi biogas, rasio C/N, uji nyala 


\section{PENDAHULUAN}

Kebutuhan energi akan semakin bertambah seiring bertambahnya jumlah penduduk di suatu wilayah. Manusia secara langsung maupun tidak langsung dalam kehidupan sehari-hari akan menggunakan energi untuk menjalani hidup. Persediaan energi sangatlah penting untuk dicari, dijaga, serta diperbarui setiap saat, sehingga persediaan energi akan mencukupi untuk kebutuhan manusia.

Kebutuhan energi yang penting untuk masyarakat salah satunya adalah kebutuhan energi listrik. Data rasio elektrifikasi atau data perbandingan jumlah rumah tangga yang telah menggunakan listrik dan jumlah rumah tangga secara keseluruhan, dapat dijadikan bahan evaluasi tentang kebutuhan energi lisrik masyarakat. Rasio elektrifikasi Indonesia tahun 2013 mencapai 78,06\%, sedangkan untuk Provinsi Lampung 72,89\% (Statistik PLN 2013). Data tersebut menunjukan bahwa masih ada $20 \%$ rumah tangga di Indonesia yang belum menggunakan instalasi listrik dari PLN.

Biogas merupakan hasil dekomposisi bahan organik melalui proses fermentasi anaerob yang menghasilkan gas bio berupa gas metana $\left(\mathrm{CH}_{4}\right)$ yang dapat dibakar. Biogas dapat dikembangkan untuk kebutuhan rumah tangga serta industri. Daerah terpencil yang belum mendapat suplai energi listrik dari PLN diharapkan mampu mengembangkan sumber energi listrik secara mandiri dengan menggunakan biogas sebagai sumber energi.

Indonesia memiliki potensi biomassa yang melimpah untuk dijadikan bahan dasar pembuatan biogas. Biomassa yang dapat dijadikan sumber energi alternatif biogas salah satunya adalah rumput gajah mini (Pennisetum purpureum cv. Mott). Rumput gajah mini merupakan salah satu rumput unggul karena produksi kualitas cukup tinggi, mudah dibudidayakan, tahan penyakit dan mampu beradaptasi pada kondisi lingkungan yang bervariasi. Produksi rata-rata rumput gajah sekitar 250 ton/ha/tahun (Santia, 2017).

Penelitian biogas ini menggunakan kotoran ayam, kotoran sapi dan rumput gajah mini sebagai substrat bahan biogas. Potensi limbah kotoran sapi yaitu seekor sapi dewasa dapat menghasilkan 23,59 kg kotoran setiap harinya (Rahayu dkk., 2009). Kotoran ayam yang digunakan yaitu kotoran ayam petelur. Seekor ayam petelur memiliki potensi limbah kotoran 0,06 kg per hari (Rachmawati, 2000).

Kotoran sapi merupakan starter yang baik dan banyak digunakan sebagai bahan baku untuk produksi biogas serta kotoran sapi memiliki rasio C/N ideal untuk produksi biogas yaitu 26,5 (Fairuz, 2015). Kotoran ayam memiliki rasio C/ $\mathrm{N}$ rendah yaitu 9,1 (Sanjaya, 2015) digunakan untuk menurunkan rasio C/N rumput gajah mini karena rasio $\mathrm{C} / \mathrm{N}$ tinggi biasa terdapat pada bahan hijauan (Wahyuni, 2013). Produksi biogas pada penelitian ini akan menggunakan digester sistem batch. Digester sistem batch digunakan karena umumnya digunakan untuk limbah padatan seperti sayuran atau hijauan (Haryati, 2006).

\section{METODOLOGI PENELITIAN}

Penelitian ini dilaksanakan pada September sampai dengan November 2016. Penelitian dilaksanakan di Laboratorium Daya Alat dan Mesin Pertanian, Jurusan Teknik Pertanian Fakultas Pertanian Universitas Lampung. Bahan yang digunakan dalam penelitian ini adalah rumput gajah mini, kotoran sapi, dan kotoran ayam. Alat yang digunakan dalam penelitian ini yaitu botol ukuran 2 liter yang digunakan sebagai digester, selang untuk saluran gas hasil produksi, balon sebagai penampung gas, termometer, $\mathrm{pH}$ meter, oven, cawan, timbangan analitik, tanur/muffle, dan alat tulis.

\subsection{Penyiapan Instalasi Biogas}

Instalasi biogas terdiri dari digester, saluran gas, dan tabung penampung hasil produksi gas. Instalasi digester menggunakan botol dengan volume $2 \mathrm{~L}$, sedangkan untuk penampung gas hasil produksi menggunakan balon. Instalasi biogas yang digunakan menggunakan instalasi sistem batch. Biogas dengan menggunakan digester sistem batch didesain untuk bahan baku organik yang berasal dari sampah sayuran atau hijauan (Wahyuni, 2013). 


\subsection{Penyiapan Bahan Baku}

Bahan yang digunakan dalam penelitian ini yaitu rumput gajah mini (pennisetum purpureum $\mathrm{cv}$. Mott), kotoran sapi dan kotoran ayam. Rumput gajah mini dipotong kecil untuk memudahkan proses penguraian oleh bakteri. Kotoran sapi dan kotoran ayam diperoleh dari peternakan terdekat. Kotoran ayam, kotoran sapi dan rumput gajah mini dicampur menjadi satu dalam digester dengan kosentrasi campuran yang ditentukan berdasarkan nilai rasio $\mathrm{C} / \mathrm{N}$.

\subsection{Perlakuan}

Perlakuan penelitian ini berdasarkan komposisi substrat bahan biogas. Bahan diukur kadar karbon dan nitrogen dari masing-masing bahan melalui analisis laboratorium sebelum dicampur. Hasil analisis bahan digunakan untuk menentukan komposisi dari masing-masing bahan dalam campuran yang disesuaikan dengan nilai rasio $\mathrm{C} / \mathrm{N}$ campuran. Perhitungan rasio $\mathrm{C} /$ $\mathrm{N}$ campuran menggunakan persamaan sebagai berikut.

$\frac{C}{N}$ campuran $=\frac{C(A) \times M(A)+C(B) \times M(B)+C(C) \times M(C)}{N(A) \times M(A)+N(B) \times M(B)+N(C) \times M(C)}$

Hasil analisis laboratorium diperoleh nilai rasio $\mathrm{C} / \mathrm{N}$ masing-masing bahan yaitu rumput gajah mini 20,18 , kotoran ayam 13,71 , dan kotoran sapi 27,52 . diukur diawal saat bahan baru dicampurkan dan setelah selesai produksi.

\section{Total Solid}

Total solid atau berat kering bahan diperoleh dengan menjemur sampel campuran bahan baku dari masing-masing perlakuan sampai kering kemudian di oven dengan suhu $103^{\circ} \mathrm{C}$ selama 24 jam. Total solid diukur pada saat awal bahan baru dicampurkan dan di akhir setelah selesai produksi biogas.

\section{Total Volatile Solid (Bahan Organik)}

Kandungan bahan organik (TVS) dan Berat Abu (BA) merupakan karakteristik bahan yang diuji dalam penelitian ini. Berat abu diperoleh dengan membakar bahan kering (TS) masing-masing sampel dengan suhu mencapai $550^{\circ} \mathrm{C}$ selama 60 menit, kemudian dihitung berat abu yang dihasilkan. Berat bahan organik diukur pada saat awal bahan baru dicampurkan dan di akhir setelah selesai produksi biogas, serta dihitung dengan persamaan berikut.

$$
\text { Bahan Organik }(T V S)=\frac{T S-B A}{T S} \times 100 \% T S
$$

\section{Hidraulic Retention Time (HRT)}

Waktu dihitung berdasarkan hari pada saat bahan dimasukan ke dalam digester sampai dengan proses produksi biogas selesai.

\section{Produksi Biogas}

Volume gas dihitung setiap hari selama berlangsungnya produksi gas. Pengukuran

Tabel 1. Perlakuan berdasarkan komposisi bahan baku

\begin{tabular}{ccccc}
\hline Perlakuan & $\begin{array}{c}\text { Kotoran } \\
\text { Ayam (\% } \\
\text { berat) }\end{array}$ & $\begin{array}{c}\text { Kotoran Sapi } \\
\text { (\% berat) }\end{array}$ & $\begin{array}{c}\text { Rumput Gajah } \\
\text { (\% berat) }\end{array}$ & $\begin{array}{c}\text { C/N Rasio } \\
\text { Campuran }\end{array}$ \\
\hline A & 0 & 100 & 0 & 27,52 \\
B & 0 & 80 & 20 & 25,47 \\
C & 20 & 60 & 20 & 22,23 \\
D & 30 & 20 & 50 & 19,18 \\
\hline
\end{tabular}

\subsection{Pengumpulan Data}

1. Suhu

Suhu yang diukur pada penelitian ini adalah suhu proses di dalam digester biogas. Pengukuran suhu dilakukan pada waktu pagi, siang, dan sore hari selama produksi biogas berlangsung. Pengukuran dilakukan dengan cara membuat instalasi khusus yang dipasang termometer untuk masing-masing perlakuan satu sampel.

\section{Derajat Keasaman (pH)}

Data $\mathrm{pH}$ campuran diperoleh dengan melakukan pengukuran menggunakan $\mathrm{pH}$ meter yang memiliki tingkat akurasi yang baik dan lebih praktis penggunaannya. Derajat keasaman $(\mathrm{pH})$ volume gas menggunakan prinsip archimedes. Balon untuk menampung gas dimasukan ke dalam bak berisi air. Volume air yang tumpah dinilai sebagai volume gas dalam balon. Volume tersebut dicatat dan dibuat grafik. Grafik dapat menggambarkan produksi biogas per hari selama fase produksi dan dapat terlihat fase produksi optimum.

\section{Produktivitas biogas}

Produktivitas biogas dihitung dengan cara volume gas yang dihasilkan per perlakuan dibagi dengan bahan organik awal dikurang bahan 
organik setelah produksi. Bahan organik yang digunakan didapatkan dari persen bahan organik yang terkandung dalam bahan.

$$
\text { Produktivitas Biogas }=\frac{\text { Produksitotal gas }}{\text { TVS Input }- \text { TVS Output }}
$$

\section{HASIL DAN PEMBAHASAN}

\subsection{Karakteristik Bahan}

\subsubsection{Rasio C/N}

Rasio C/N merupakan perbandingan antara karbon dan nitrogen pada suatu bahan organik. Dua unsur utama yang membentuk substrat bahan organik adalah nitrogen dan karbon. Dua unsur tersebut digunakan mikroorganisme sebagai sumber energi dalam proses perombakan (Wahyuni, 2013). Pengukuran rasio $\mathrm{C} / \mathrm{N}$ dilakukan di Laboratorium Jurusan Ilmu Tanah Fakultas Pertanian Universitas Lampung. Hasil pengukuran rasio $\mathrm{C} / \mathrm{N}$ bahan digunakan untuk menentukan rasio $\mathrm{C} / \mathrm{N}$ campuran. Rasio $\mathrm{C} / \mathrm{N}$ bahan hasil pegukuran pada Tabel 2 .
Rasio $\mathrm{C} / \mathrm{N}$ substrat yang rendah apabila diproses secara anaerob dapat menyebabkan amonifikasi dan dapat meracuni bakteri yang ada di dalam digester (Ratnaningsih dkk, 2009). Hal ini sama dengan yang dinyatakan oleh Wahyuni (2013) bahwa apabila rasio $\mathrm{C} / \mathrm{N}$ sangat rendah menyebabkan nitrogen akan bebas dan berakumulasi dalam bentuk amoniak $\left(\mathrm{NH}_{4}\right)$. Perlakuan $\mathrm{D}$ memiliki nilai rasio $\mathrm{C} / \mathrm{N}$ yang rendah yaitu 19,18.

Tanimu dkk (2014) menyatakan usaha meningkatkan rasio $\mathrm{C} / \mathrm{N}$ menjadi 26-30 dapat menambah produksi metana biogas. Wahyuni (2013) menyatakan nilai optimum rasio $\mathrm{C} / \mathrm{N}$ untuk produksi biogas yaitu 25-30. Perlakuan A dan $\mathrm{B}$ memiliki rasio $\mathrm{C} / \mathrm{N}$ optimum untuk produksi biogas yaitu 27,52 dan 25,47.

Rasio C/N optimum menurut Dioha dkk (2013) yaitu 20-30. Perlakuan $\mathrm{C}$ memiliki rasio $\mathrm{C} / \mathrm{N}$ 22,23 yang juga dapat menghasilkan biogas secara optimum.

Tabel 2. Rasio C/N bahan

\begin{tabular}{lccc}
\hline \multicolumn{1}{c}{ Bahan } & $\begin{array}{c}\text { C Organik } \\
(\%)\end{array}$ & $\begin{array}{c}\text { N Total } \\
(\%)\end{array}$ & Rasio C/N \\
\hline Rumput Gajah & 46,62 & 2,31 & 20,18 \\
Kotoran Ayam & 30,43 & 2,22 & 13,71 \\
Kotoran Sapi & 41,01 & 1,49 & 27,52 \\
\hline
\end{tabular}

Kotoran sapi memiliki rasio C/N 27,52 paling tinggi dibandingkan dengan bahan lainnya. Kotoran ayam memiliki rasio $\mathrm{C} / \mathrm{N}$ paling rendah yaitu 13,71 . Bahan dengan rasio $\mathrm{C} / \mathrm{N}$ yang rendah akan menghasilkan rasio $\mathrm{C} / \mathrm{N}$ campuran yang rendah pula. Rasio $\mathrm{C} / \mathrm{N}$ campuran hasil perhitungan ditunjukan pada tabel 3 .

\subsubsection{Karakteristik bahan campuran}

Karakteristik bahan campuran setelah diuji di laboratoium hasil yang diperoleh pada Tabel 4

Berat padatan organik yang habis terbakar pada proses pengabuan didefinisikan sebagai padatan tak stabil. Kandungan padatan tak stabil sebagai

Tabel 3. Rasio C/N campuran

\begin{tabular}{cccc}
\hline Perlakuan & $\begin{array}{c}\text { C Organik } \\
(\%)\end{array}$ & N Total (\%) & $\begin{array}{c}\text { C/N Rasio } \\
\text { Campuran }\end{array}$ \\
\hline A & 4101 & 149 & 27,52 \\
B & 4213,2 & 165,4 & 25,47 \\
C & 4001,6 & 180 & 22,23 \\
D & 4064,1 & 211,9 & 19,18 \\
\hline
\end{tabular}

Wahyuni (2013) menyatakan nilai rasio C/N yang terlalu tinggi akan menghambat kinerja mikroba, sehingga produksi gas metana akan menjadi rendah. Nilai rasio yang terlalu rendah akan mengakibatkan terbantuknya asam-asam oraganik yang tinggi (Wahyuni, 2013). faktor yang mempengaruihi potensi produksi biogas. Padatan tak stabil yang semakin tinggi terkandung dalam satu unit volume dari bahan segar akan menghasilkan produksi gas yang lebih banyak (Wahyuni, 2013). 
Tabel 4. Nilai total solid dan total volatile solid

\begin{tabular}{ccccc}
\hline \multirow{2}{*}{ Perlakuan } & \multicolumn{2}{c}{ Awal } & \multicolumn{2}{c}{ Akhir } \\
\cline { 2 - 5 } & TS (\%BB) & $\begin{array}{c}\text { TVS } \\
(\% \mathrm{TS})\end{array}$ & $\begin{array}{c}\text { TS } \\
(\% \mathrm{BB})\end{array}$ & $\begin{array}{c}\text { TVS } \\
(\% \mathrm{TS})\end{array}$ \\
\hline $\mathrm{A}$ & 23,82 & 76,76 & 18,34 & 72,10 \\
$\mathrm{~B}$ & 9,06 & 79,62 & 6,07 & 75,60 \\
$\mathrm{C}$ & 11,00 & 76,94 & 8,98 & 74,00 \\
D & 18,49 & 78,64 & 15,30 & 75,03 \\
\hline
\end{tabular}

Total solid dan volatile solid akhir menunjukan terjadinya penurunan nilai. Hal ini bisa dikarenakan terjadi proses dekomposisi bahan oleh bakteri pengurai. Penurunan total solid dan volatile solid berindikasi dengan peningkatan kadar gas metana yang dihasilkan. Volatile solid merupakan substrat (sumber makanan) bagi mikroorganisme non metanogen yang bekerja pada tahap awal produksi biogas, penurunan volatile solid menunjukkan di dalam biodigester terjadi proses degradasi senyawa organik oleh mikroorganisme non metanogen.

Mikroorganisme di dalam biodigester berangsurangsur mencapai pertumbuhan yang setimbang antara mikroorganisme non metanogen dan metanogen, kondisi ini dapat dilihat dari produksi gas metana yang meningkat. (Ni'mah, 2014).

Jenis bahan organik yang digunakan sebagai bahan baku merupakan faktor yang sangat penting karena berpengaruh terhadap lama waktu dekomposisi. Bahan organik berupa limbah pertanian hijauan yang mengandung selulosa dan lignin lebih lama untuk terdekomposisi (Wahyuni, 2013).

\subsection{Suhu Proses dan Suhu Lingkungan}

Faktor lain yang mempengaruhi produksi biogas salah satunya adalah suhu. Perlakuan pada penelitian ini dibiarkan pada kondisi ruang atau tidak ada perlakuan khusus terkait suhu. Suhu pada penelitian ini diukur setiap hari dengan rentang waktu pagi, siang dan sore. Suhu diukur meliputi suhu di dalam digester dan suhu ruangan/lingkungan. Suhu berpengaruh terhadap mikroorganisme pengurai dalam proses fermentasi anaerob. Suhu rata-rata hasil pengukuran dapat dilihat pada Gambar 1.

Hasil pengukuran suhu menunjukan suhu lingkungan maupun suhu setiap perlakuan tidak berubah secara ekstrim pada pagi, siang dan sore hari. Perubahan suhu yang terlalu ekstrim di dalam digester akan mengakibatkan penurunan populasi mikroorganisme sehingga dengan cepat akan berpengaruh terhadap penurunan produksi biogas (Wahyuni, 2013).

Suhu proses pada masing-masing perlakuan tidak ada yang mencapai kondisi mesofilik $35^{\circ} \mathrm{C}$ maupun kondisi termofilik $50^{\circ} \mathrm{C}$. Proses

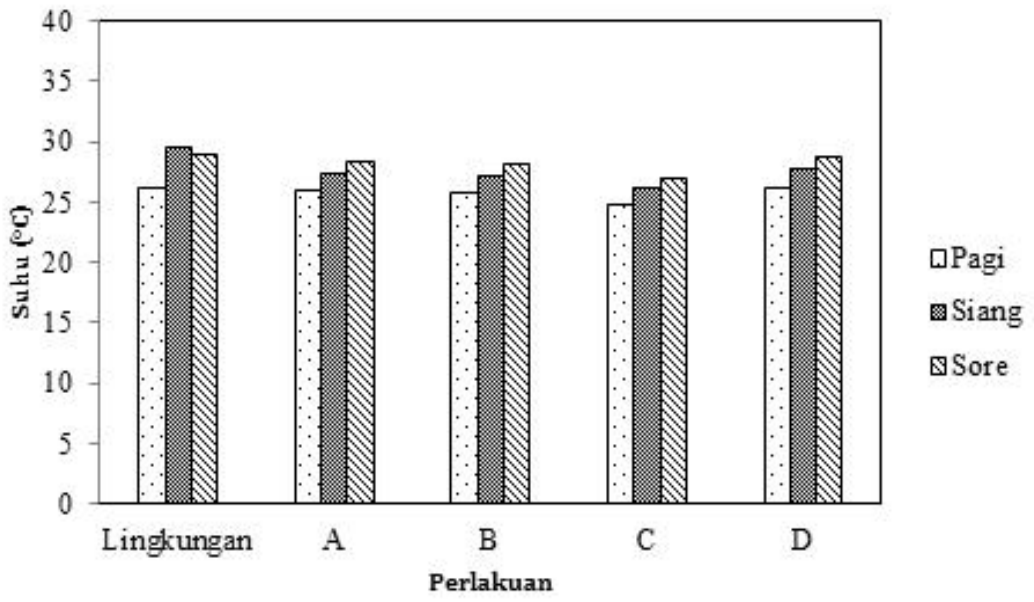

Gambar 1. Suhu rata-rata perlakuan dan lingkungan 
penguraian bahan organik oleh mikroorganisme pada tahap asidifikasi menghasilkan asam asetat akan diurai pada tahap metanogenesis yang salah satunya menjadi gas metana $\left(\mathrm{CH}_{4}\right)$. Bakteri melakukan aktivitas tertinggi pada kisaran suhu $35^{\circ} \mathrm{C}$ hingga $55^{\circ} \mathrm{C}$, diatas suhu tersebut aktivitas menurun sehingga bakteri tidak beraktivitas baik dalam pertumbuhannya maupun produksi asam asetat (Darmanto dkk, 2012).

Ratnaningsih dkk (2009) menyatakan suhu kerja yang optimum untuk penghasil biogas adalah suhu $35^{\circ} \mathrm{C}$ dan pencernaan anaerobik dapat berlangsung pada kisaran suhu $5^{\circ} \mathrm{C}$ sampai $55^{\circ} \mathrm{C}$. Rashed (2014) menyatakan bahwa total produksi tertinggi biogas pada kondisi mesofilik dan dalam waktu retensi yang lebih lama. Hasil produksi biogas pada kondisi termofilik lebih tinggi hanya dalam sepuluh hari pertama produksi biogas.

\subsection{Derajat Keasaman (pH)}

Rata-rata nilai derajat keasaman dapat dilihat pada Gambar 2. Rata-rata nilai $\mathrm{pH}$ awal diperoleh perlakuan D memiliki nilai $\mathrm{pH}$ netral, sedangkan perlakuan $\mathrm{A}, \mathrm{B}$, dan $\mathrm{C}$ mendekati nilai $\mathrm{pH}$ netral. Rata-rata nilai $\mathrm{pH}$ akhir pada semua perlakuan bersifat asam.
Budiyono dkk (2013) menyatakan bahwa metode terbaik untuk memproduksi biogas pada komposisi rentang $\mathrm{pH}$ 6-8 dan produksi biogas tertinggi pada $\mathrm{pH} 7$. Nilai optimum untuk fermentasi anaerob yaitu 5,5-8,5. Peningkatan asam yang berlebihan dapat menghambat metanogen (Verma, 2002).

\subsection{Produksi Gas}

Produksi biogas merupakan indikasi kinerja dari mikroba dalam melakukan penguraian bahan organik melalui proses fermentasi anaerob. Produksi gas kumulatif setiap perlakuan secara rata-rata ditampilkan pada Gambar 3.

Produksi biogas kumulatif dari masing-masing perlakuan berkisar 2000-5000 ml. Produksi biogas kumulatif berbeda dari masing-masing perlakuan. Perlakuan A memiliki produksi biogas kumulatif paling tinggi yaitu $4916 \mathrm{ml}$. Perlakuan B produksi biogas kumulatif tidak berbeda jauh dengan perlakuan A yaitu $4610 \mathrm{ml}$. Produksi kumulatif perlakuan C yaitu $3909 \mathrm{ml}$. Perlakuan D memiliki produksi kumulatif paling rendah di antara perlakuan lain yaitu $2640 \mathrm{ml}$.

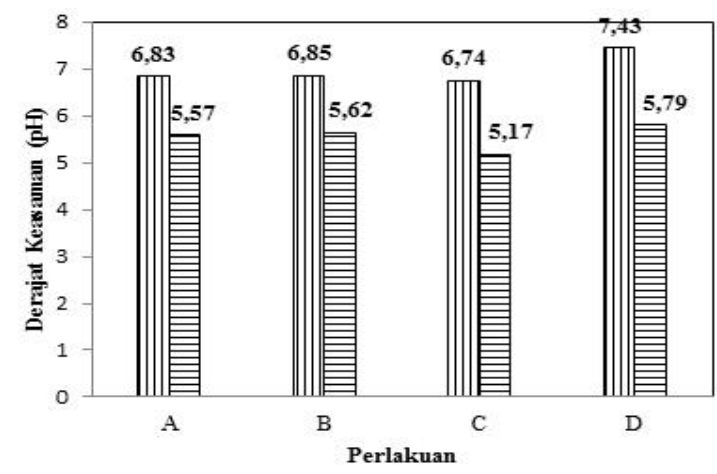

Gambar 2. Nilai pH awal dan akhir

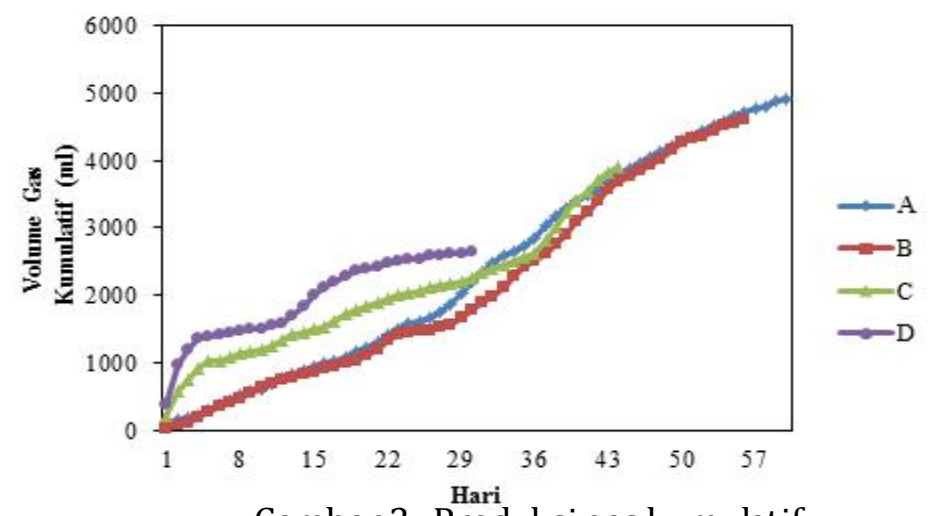

Gambar 3. Produksi gas kumulatif 
Perlakuan A rentang waktu produksi biogas selama 60 hari, perlakuan B 56 hari, perlakuan C 44 hari dan perlakuan D selama 30 hari. Hal ini ditunjukan pada Gambar 3. Produksi rata-rata gas setiap hari selama rentang waktu produksi biogas masing-masing perlakuan yaitu perlakuan A $82 \mathrm{ml} /$ hari, perlakuan B $82 \mathrm{ml} /$ hari, perlakuan C $89 \mathrm{ml} /$ hari dan perlakuan D $88 \mathrm{ml} /$ hari. yang lebih tinggi. Bahan mengalami respirasi karena saat penutupan reaktor sejumlah oksigen akan masuk kedalamnya. Bakteri aerob akan mendapatkan oksigen untuk respirasi apabila berada di daerah permukaan yang terpapar langsung dengan udara (Fairuz, 2015). Produktivitas biogas dari masing-masing perlakuan ditampilkan pada Gambar 5.

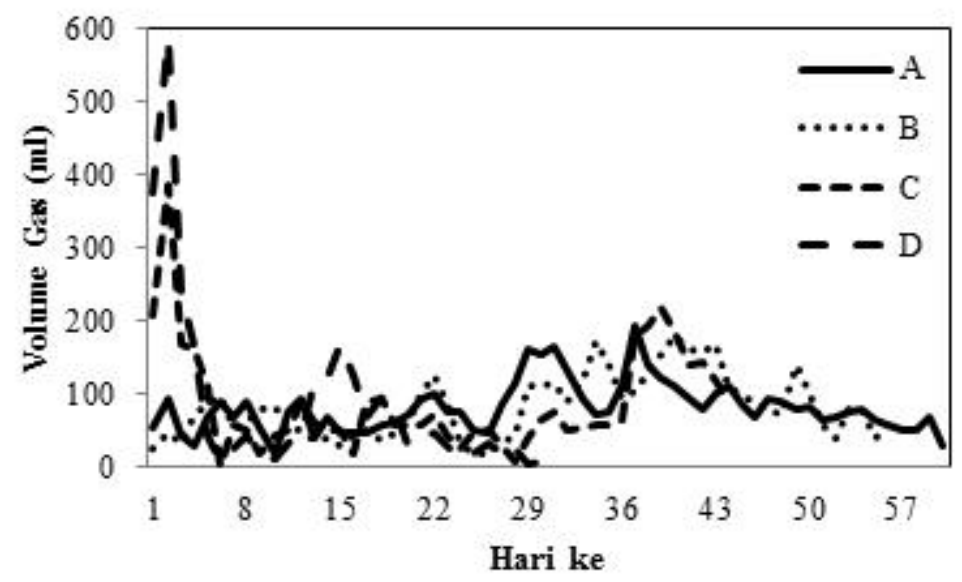

Gambar 4. Produksi gas harian

Produksi biogas yang berbeda antar perlakuan diduga disebabkan oleh rasio $\mathrm{C} / \mathrm{N}$ yang berbeda. Perlakuan A dengan bahan baku kotoran sapi murni tanpa campuran bahan lain memiliki rasio $\mathrm{C} / \mathrm{N}$ paling optimum untuk menghasilkan biogas. Perlakuan D memiliki rasio $\mathrm{C} / \mathrm{N}$ paling rendah di bawah standar optimum 20 untuk produksi biogas sehingga hasil produksi biogasnya lebih rendah. Perlakuan $\mathrm{B}$ memiliki rasio $\mathrm{C} / \mathrm{N}$ tidak jauh berbeda dengan perlakuan A sehingga hasil produksi biogas tidak jauh berbeda. Perlakuan C dan D memiliki produksi gas tertiggi di hari kedua kemudian produksi gas menurun. Hal ini diduga disebabkan pada tahap terjadi proses respirasi sehingga diduga menghasilkan gas $\mathrm{CO}_{2}$
Produktivitas biogas perlakuan A $60,71 \mathrm{~mL} / \mathrm{g}$ VS, perlakuan B 109,58 mL/g VS, perlakuan C 134,29 mL/g VS, dan perlakuan D 53,88 mL/g VS. Perlakuan $\mathrm{C}$ memiliki produktivitas biogas paling tinggi dibandingkan perlakuan lain. Produksi gas yang tinggi tidak menentukan tingkat produktivitas biogas yang tinggi pula dan sebaliknya. Hal ini diduga disebabkan oleh perbedaan kemampuan mikroorganisme pengurai dalam mengurai bahan organik yang tersedia dalam substrat biogas masing-masing perlakuan. Jumlah mikroorganisme pengurai yang berbeda tiap perlakuan diduga juga berpengaruh terhadap perbedaan produktivitas biogas.

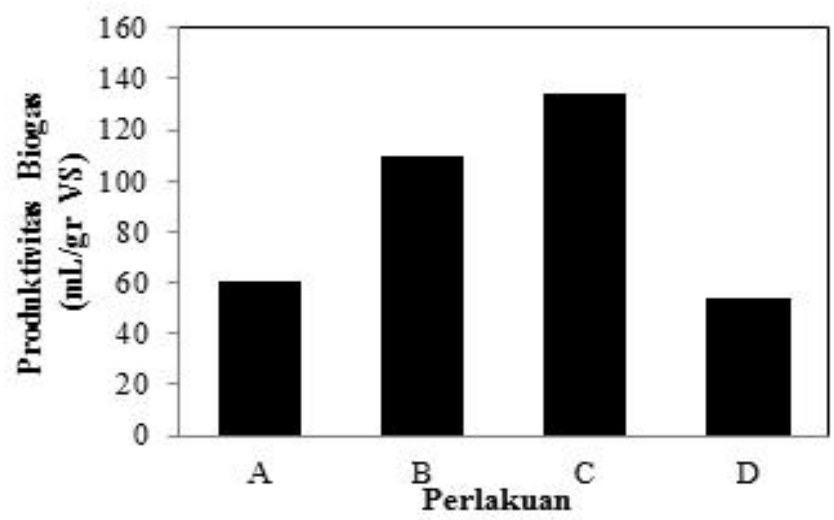

Gambar 5. Produktivitas biogas masing-masing perlakuan 


\subsection{Uji Nyala}

Uji nyala terhadap gas yang dihasilkan melalui proses fermentasi anaerob merupakan salah satu cara untuk mengetahui terdapat atau tidaknya metana $\left(\mathrm{CH}_{4}\right)$ dalam gas tersebut. Gas hasil produksi yang mengandung metana akan ikut
Perlakuan C diduga mengalami proses metanogenesis lebih lama dibandingkan perlakuan A dan B sehingga perlakuan C produksi metana lebih lama terbentuk.

Hasil uji nyala perlakuan $\mathrm{C}$ dapat diliat pada Gambar 7. Uji nyala perlakuan C yang kedua

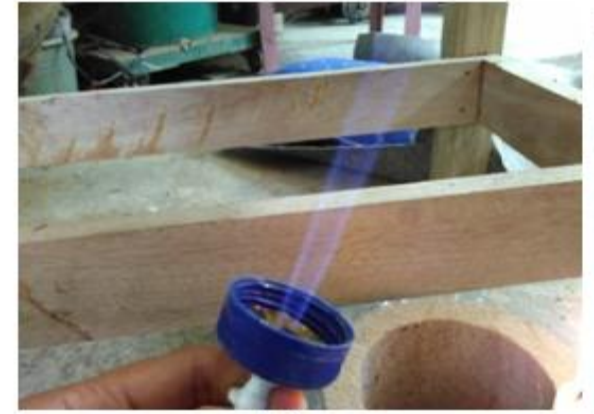

(a)

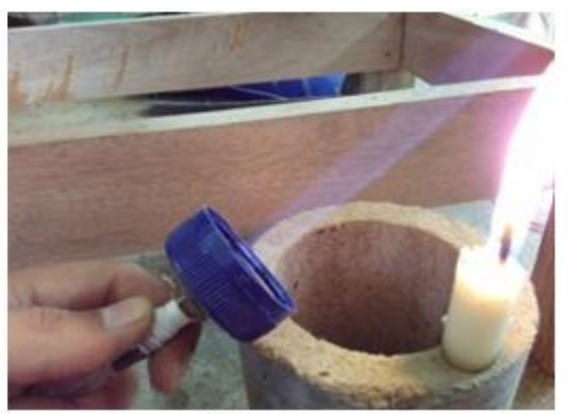

(b)

Gambar 6. Hasil uji nyala (a) perlakuan A dan (b) perlakuan B
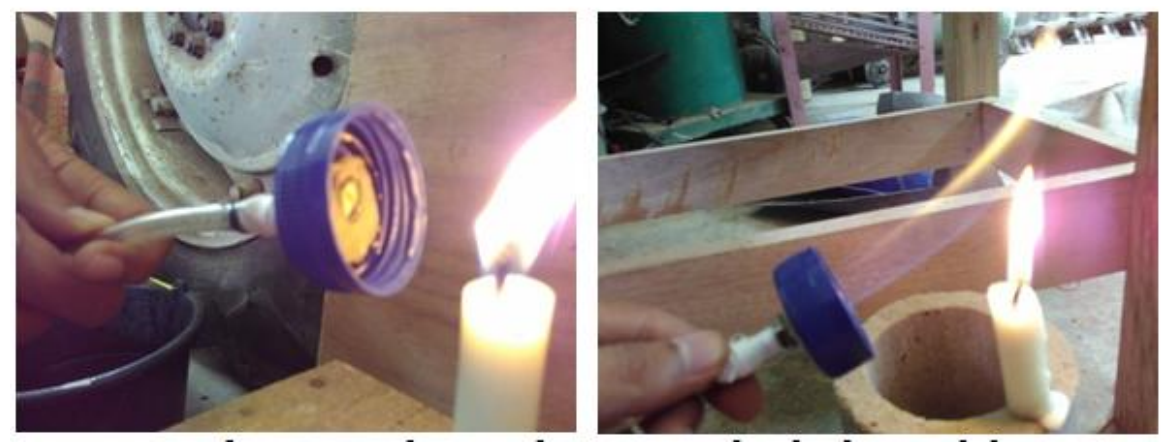

Gambar 7. Hasil uji nyala pertama dan kedua perlakuan C

terbakar apabila didekatkan pada sumber api. Perlakuan A dan B setelah selesai produksi gas dilakukan uji nyala dan menghasilkan api berwarna biru. Hal ini menandakan bahwa terdapat unsur metana di dalam gas hasil produksi perlakuan A dan B. Metana yang terkandung di dalam gas dapat terbakar maka diperkirakan kandungan metana dalam gas sekitar 45\% (Ihsan, 2013). Hasil uji nyala perlakuan A dan B dapat dilihat pada Gambar 6.

Perlakuan D setelah dilakukan uji nyala gas hasil produksi tidak dapat menyala. Hal ini menunjukan bahwa kandungan metana di dalam gas produksi perlakuan $\mathrm{D}$ sangat sedikit. Perlakuan C dilakukan uji nyala sebanyak dua kali. Hasil uji nyala pada uji pertama pada hari ke-31 gas tidak dapat terbakar. Uji nyala kedua pada perlakuan C pada hari ke-45 gas dapat terbakar. Tahap fermentasi anaerob terdiri dari proses hidrolisis, asidifikasi, dan metanogenesis. menghasilkan api berwana biru dan kuning. Kadar $\mathrm{CO}_{2}$ berpengaruh terhadap pembakaran $\mathrm{CH} 4$. Pembakaran bahan bakar tanpa $\mathrm{CO}_{2}$ akan menghasilkan api berwarna biru sedangkan api berwarna kuning kemerahan akibat adanya $\mathrm{CO}_{2}$ (Uwar dkk, 2012).

\section{DAFTAR PUSTAKA}

Budiyono., M.E. Pratiwi, dan I.N. Sinar. 2013. Pengaruh Metode Fermentasi, Komposisi Umpan, pH Awal, dan Variasi Pengenceran Terhadap Produksi Biogas dari Vinasse. Jurnal Penelitian Kimia. 9. 2. 1-12.

Darmanto, A., S. Soeparman, dan D. Widhiyanuriawan. 2012. Pengaruh Kondisi Temperatur Mesophilic $\left(35^{\circ} \mathrm{C}\right)$ dan Thermophilic $\left(55^{\circ} \mathrm{C}\right)$ Anaerob Digester Kotoran Kuda Terhadap Produksi Biogas. Jurnal Rekayasa Mesin. 3.2.317-326. 
Dioha, I.J., C.H. Ikeme, T. Nafi'u, N.I. Soba, dan Yusuf. 2013. Effect of Carbon to Nitrogen Ratio on Biogas Production. International Research of Natural Sciences. 1.3.1-10.

Fairuz, A. 2015. Pengaruh Penambahan Ampas Kelapa dan Kulit Pisang Terhadap Produksi Biogas dari Kotoran Sapi. Jurnal Teknik Pertanian Lampung. 4. 2. 91-98

Haryati, T. 2006. Biogas: Limbah Peternakan yang Menjadi Sumber Energi Alternatif. Wartazoa. 16. 160-169.

Ihsan, A., S. Bahri, dan Musafira. 2013. Produksi Biogas Menggunakan Cairan Isi Rumen Sapi dengan Limbah Cair Tempe. Online Jurnal of Natural Science. 2.2. 27-35

Ni'mah, L. 2014. Biogas from Solid Waste of Tofu Production and Cow Manure Mixture: Composition Effect. Chemica. 1.1.1-9

Rachmawati, S. 2000. Upaya Pengelolaan Lingkungan Usaha Peternakan Ayam. Watazoa. 9.2.

Rashed, M.B. 2014. The Effect of Temperature on the biogas Production from Olive Pomace. ISSUE. 3. 16.

Ratnaningsih., H. Widyatmoko dan T. Yananto. 2009. Potensi Pembentukan Biogas pada Proses Biodegradasi Campuran Sampah Organik Segar dan Kotoran Sapi dalam Batch Reaktor Anaerob. Jurnal Universitas Trisakti. 5 (1) : 20-26.

Sanjaya, D. 2015. Produksi Biogas dari Campuran Kotoran Sapi dengan Kotoran Ayam. Jurnal Teknik Pertanian Lampung. 4.2.127-136

Santia., S.D. Anis dan C.L. Kaunang. 2017. Pengaruh Tinggi dan Jarak Waktu Pemotongan Rumput Gajah Dwarf (pennisetum purpureum cv.mott) terhadap Pertumbuhan Vegetatif dan Produksi Bahan Kering. Jurnal Zootek. 37.1.116-122

Tanimu, M.I., T.I.M. Ghazi, R.M. Harun, dan A. Idris. 2014. Effect of Carbon to Nitrogen Ratio of Food Waste on Biogas Methane
Jurnal Teknik Pertanian LampungVol.6, No. 3: 151-160

Production in a Batch Mesophilic Anaerobic Digester. International Journal Of Innovation. 5.2.

Uwar, N.A., I. Wardana. dan D. Widhiyanuriawan. 2012. Karakteristik Pembakaran CH4 dengan Penambahan CO2 pada Model Helle-Shaw Cell pada Penyalaan Bawah. Jurnal Rekayasa Mesin. 3.1.249-257.

Verma, S. 2002. Anaerobic Digestion of Biodegradable Organics in Municipal Solid Wastes. Columbia University

Wahyuni, S. 2013. Biogas Energi Alternatif Pengganti BBM, Gas, dan Listrik. PT Agromedia Pustaka. Jakarta

Wahyuni, S. 2013. Panduan Praktis Biogas. Penebar Swadaya. Jakarta 
Produksi biogas dari campuran.... (Yasin Y, Tamrin dan Sugeng T) 